\title{
Evaluation of Floral Cuts on Eriophyid Mite Retention on Knock Out and Multiflora Rose Cuttings
}

\author{
Katherine M. Solo, ${ }^{1,+}$ Sara B. Collins, ${ }^{1}$ Liesel G. Schneider, ${ }^{2}$ M. R. Hajimorad, ${ }^{1}$ Frank A. Hale, ${ }^{3}$ John B. Wilkerson, ${ }^{4}$ Alan S. Windham, ${ }^{3}$ \\ and Mark T. Windham ${ }^{4}$ \\ ${ }^{1}$ Department of Entomology and Plant Pathology, University of Tennessee, Knoxville, TN 37996 \\ ${ }^{2}$ Department of Animal Science, University of Tennessee, Knoxville, TN 37996 \\ ${ }^{3}$ Department of Entomology and Plant Pathology, University of Tennessee, Nashville, TN 37211 \\ ${ }^{4}$ Department of Biosystems Engineering and Soil Science, University of Tennessee, Knoxville, TN 37996
}

Accepted for publication 12 March 2019.

\section{Abstract}

Current eriophyid mite quantification techniques require transportation of the Rosa spp. cuttings to the laboratory. It is thought that the change in xylem hydraulic conductance within the cut cane could trigger the mites to abandon their host, owing to the changes to the microenvironments that these mites are inhabiting. An experiment was conducted to determine the necessity of floral cuts (reducing stem embolisms by an additional cut underwater) for the retention of eriophyid mites during transit. Four groups of plants (rose rosette virus (RRV)-free Knock Out roses, RRV-infected Knock Out roses, RRV-free multiflora roses, and RRVinfected multiflora roses) were evaluated at different time intervals $(0.5,2,4,8,24,48,72$, and $96 \mathrm{~h}$ postharvest) to assess mite populations on each plant (number of mites per gram of tissue). Cut type (floral or dry cut) and rose species were found not to have a significant effect on the number of mites per gram of tissue found, indicating that floral cuts are not needed for accurately estimating eriophyid mite populations. Rose cuttings infected with RRV were found to have an average of 46 times more mites per gram in comparison with RRV-free cuttings.

Keywords: floral cut, diagnostics, experiment design, mites, vectors rose rosette virus, rose
The eriophyid mite, Phyllocoptes fructiphilus Keifer, is the only known mite to vector rose rosette virus (RRV), which is associated with rose rosette disease (RRD) (Allington et al. 1968; Amrine et al. 1988; Gergerich and Kim 1983; Laney et al. 2011). P. fructiphilus have restricted movement owing to the lack of hind legs and their small size, 140 to $170 \mu \mathrm{m}$ (Sabelis and Bruin 1996). They are refuge-seeking mites, inhabiting protected microenvironments on Rosa spp. such as flower buds, under sepal trichomes, crevices between the petiole and stem, and young folded leaves (Allington et al. 1968; Kassar and Amrine 1990; Keifer 1940).

Eriophyid mites prefer to feed on the succulent new growth where the plant tissue is thinner and softer to allow their stylets access to the plant sap (Amrine 1996; Sabelis and Bruin 1996). To initiate feeding, mites probe the substrate for suitability (Krantz 1973). If the substrate is suitable, the body enters a feeding stance by bending slightly, anchoring to the substrate with the rostrum, and contracting the telescopic palpal segments, allowing the cheliceral stylets to enter the host tissue (Krantz 1973; Westphal and Manson 1996). Feeding can last from $1 \mathrm{~min}$ to $1 \mathrm{~h}$ (Westphal et al. 1990).

${ }^{\dagger}$ Corresponding author: K. M. Solo; E-mail: kbaker46@vols.utk.edu

Funding: The authors thank the National Institute of Food and Agriculture Specialty Crop Research Initiative Grant (2014-07901), Combating Rose Rosette Disease: Short Term and Long Term Approaches, for providing funding for this project.

The author(s) declare no conflict of interest.

(C) 2019 The American Phytopathological Society
The microenvironments that these mites occupy on the rose are always changing, whether it is because the tissue ages, available nutrients are reduced, or the cuticle thickens; it is sometimes necessary for these mites to migrate to new locations on the plant or to new host plants (Sabelis and Bruin 1996). Mites travel to new microenvironments on the host plant using ambulatory movements. They can also use air currents to travel to a new host plant in a process called ballooning. When ballooning, mites move to the plant tips, stand up on their caudal sucker on their posterior end, and wave their legs in the air, waiting for a current strong enough to pull them off the substrate (Bergh and Weiss 1993; Davis 1964; Michalska et al. 2010; Nault and Styer 1969; Sabelis and Bruin 1996; Shvanderov 1975; Smith 1959). Eriophyid mites do not have eyes; rather, they have a light-sensing ability that allows them to follow light gradients out of their microenvironments to leaf tips for take-off (Shevchenko 1970). Furthermore, it appears that ballooning is an active choice of eriophyid mites, because nearly all mites captured using air sampling methods are adults, and most of them protogyne females, which will reproduce in the same season (Davis 1964; Krantz 1973; Nault and Styer 1969; Sabelis and Bruin 1996).

Environmental conditions that encourage aerial dispersion may include high temperatures, high humidity, approaching low pressure areas, or strong winds (Michalska et al. 2010), in addition to changes in the host plant's condition. Aerial dispersion is reduced or absent when there are low wind speeds, low temperatures, and during darkness (Sabelis and Bruin 1996). Eriophyid mites have been collected at wind speeds higher than 11 and $24 \mathrm{~km} / \mathrm{h}$ and at greater numbers when temperatures are higher than $18^{\circ} \mathrm{C}$ (Davis 
1964; Nault and Styer 1969). On any leaf surface, there are two layers of air, a fixed layer only a few microns thick and a laminar layer in which air flows perpendicular to the substrate surface (Shevchenko 1970). As wind speeds increase, the laminar layer thickness decreases, allowing vertical mites more access to air currents with enough strength to pull them from the substrate (Shevchenko 1970). Despite these reports, the specific factors that facilitate aerial dispersion of $P$. fructiphilus are unknown.

Most of the extraction techniques used to quantify the number of eriophyid mites require transportation of the rose cuttings to the laboratory (Faraji et al. 2004; Gabi and Mészáros 2001; Monfreda et al. 2007; Pérez-Moreno and Moraza-Zorilla 1998; Siriwardena et al. 2005; Zacharda et al. 1988). During transportation, it is crucial that mite loss is minimized for accurate counting results. To reduce disruption of the microenvironments, floral cuts (a secondary cut performed underwater) are used to avoid introducing emboli to the stem, which interrupts the xylem hydraulic conductance. Floral cuts rehydrate roses, even in environments in which high water flow rate is required (Evans et al. 1996). Floral cut treatments are used to reduce microenvironment changes that may induce a migratory response from eriophyid mites on roses. Floral cuts are assumed to be an important step in maintaining eriophyid mite populations on rose tissue.

Traditionally, RRD and $P$. fructiphilus research utilized the multiflora rose as the host plant, but current research is focusing more on ornamental cultivars of roses. The objective is aimed at determining whether mites react differently to rose cuttings treated with floral cuts and untreated as dry cuttings. In this study, treatments of collected rose samples from the cultivated rose Knock Out and multiflora roses were compared to determine if eriophyid mites behaved similarly on both types of roses. Samples were gathered from four plot types (RRV-free Knock Out roses, RRV-infected Knock Out roses, RRV-free multiflora roses, and RRV-infected multiflora roses). Samples were analyzed at different hours postharvest to see whether mite populations are affected by the treatment of floral cuts, types of rose, and RRV infection.

The hypothesis was that there would be a greater number of eriophyid mites found in samples treated with floral cuts, no difference in the number of mites found on Knock Out roses and multiflora roses, and a greater number of mites on RRV-infected roses over RRV-free roses.

\section{Plant Material Acquisition}

Highly symptomatic rose plots that were naturally infected with RRV and asymptomatic rose plots located on or near the University of Tennessee Plateau AgResearch and Education Center in Crossville, Tennessee, in October 2017 were used in this experiment. Plots used for the collection of rose material were selected based on the following criteria: visible symptomatic tissue/ asymptomatic tissue for greater than 1 month, a rose plant large enough to collect $160 \mathrm{~g}$ of tissue (or 16 samples), and a plot with at least three plants in the same environmental conditions. Four types of plots were used: RRV-free Knock Out roses, RRV-infected Knock Out roses, RRV-free multiflora, and RRV-infected multiflora. From each plot type, eight samples (one sample to be processed at each time interval: $0.5,2,4,8,24,48,72$, and $96 \mathrm{~h}$ postharvest) were taken from three separate plants, for a total of 24 samples, all treated with a floral cut at the time of collection in the field. Each sample contained approximately $10 \mathrm{~g}$ of rose tissue, including both leaves and stems. Additionally, each plant yielded eight more samples, for a total of 24 samples untreated as a dry cut. This accumulated in a sum of 48 samples ( 24 floral cuts and 24 dry cuts) per plot and 192 samples for all four plots combined. The samples were collected at the same time and held in the laboratory until the time-interval processing was performed accordingly. The rose tissue was analyzed for presence of RRV using TaqMan quantitative reverse transcription polymerase chain reaction (RTqPCR) with RRV2 forward, RRV2 reverse, and a TaqMan RRV2 probe primers (Dobhal et al. 2016).

\section{RNA Purification}

Using composite samples from each of the four plots, total RNAs were extracted using the direct antigen capture method (Babu et al. 2017). Two grams of leaves were ground in an enzyme-linked immunosorbent assay sample mesh bag (Agdia, Elkhart, IN) with $7 \mathrm{ml}$ of $1 \%$ phosphate buffered saline (PBST, pH between 7.2 and 7.6, with Tween 20) buffer using a pestle. A subsample of 1,000 $\mu \mathrm{l}$ of the simple tissue sap/buffer solution was transferred to an Eppendorf tube and incubated for $2 \mathrm{~min}$ on an ice block in the refrigerator. Eppendorf tubes were poured out and rinsed with 1,000 $\mu l$ of PBST buffer six times, discarding the wash each time. All remaining fluid was slung out of the tube. Sample tubes were placed on a heating block for $1 \mathrm{~min}$ at $95^{\circ} \mathrm{C}$ and then transferred back to the ice block and placed in $-20^{\circ} \mathrm{C}$ for 1 to 2 min. An RNA elution master mix was made by combining $2 \mu \mathrm{l}$ of RNasin (Promega, Madison, WI) with $30 \mu \mathrm{l}$ of RNase-free water. Each sample tube received $32 \mu \mathrm{l}$ of the RNA elution master mix to elute RNA from the column surfaces. Samples were vortexed and then centrifuged at $2,680 \times g$ for $10 \mathrm{~s}$. The samples were stored at $-20^{\circ} \mathrm{C}$ until TaqMan RT-qPCR was performed.

\section{TaqMan RT-qPCR}

One-step TaqMan RT-qPCR assays were performed using RRV2 forward and RRV2 reverse primers and a TaqMan RRV2 Probe (Dobhal et al. 2016), using an Applied Biosystems QuantStudio 6 Flex Fast Real-time PCR System (Thermo-Fisher, Carlsbad, CA). The reaction mix consisted of $10.1 \mu l$ of RNase-free water, $5 \mu l$ of TaqMan Fast Virus 1 Step Master Mix (containing DNA polymerase, enzyme, dNTPs, recombinant ribonuclease inhibitor, dye, and buffer) (Thermo-Fisher), $2 \mu \mathrm{l}(10 \mu \mathrm{M})$ of Primer mix F/R RRV2, $0.5 \mu \mathrm{l}(10 \mu \mathrm{M})$ of TaqMan RRV2 Probe, $0.4 \mu \mathrm{l}$ of Rox Reference Dye (50x) (Thermo-Fisher), and $2 \mu$ l of RNA template in a final reaction volume of $20 \mu \mathrm{l}$. Two positive and two negative controls were used in each TaqMan RT-qPCR experiment. The positive control consisted of two RNA extracts from a rose naturally infected by RRV, one extracted and frozen 1 month before the experiment and one extracted at the time of the experiment from the same rose sample from Durant, Oklahoma. The negative controls consisted of an asymptomatic rose from the University of Tennessee Plateau AgResearch and Education Center and one simply RNase-free water. The TaqMan RT-qPCR amplification protocol consisted of an initial stage of $50^{\circ} \mathrm{C}$ for $5 \mathrm{~min}$, a hold stage of $95^{\circ} \mathrm{C}$ for $20 \mathrm{~s}$, followed by 40 cycles of $95^{\circ} \mathrm{C}$ for $15 \mathrm{~s}$, and $60^{\circ} \mathrm{C}$ for $1 \mathrm{~min}$. Data acquisition and analysis were preformed using Applied Biosystems QuantStudio 6 software.

\section{Time Interval Mite Extractions}

Postharvest mite counts were conducted at the following time intervals: $0.5,2,4,8,24,48,72$, and $96 \mathrm{~h}$ at $23^{\circ} \mathrm{C}$. Each sample was cut into approximately $1-\mathrm{cm}$ pieces and weighed. Ten grams of tissue were submerged in approximately $100 \mathrm{ml}$ of Clorox regular bleach/Dawn dish soap dilution. Samples were hand stirred for a maximum of $5 \mathrm{~min}$. The tissue solution was poured through a series of sieves: 80, 270, and 500, with mesh openings measured at 180, 53, and $25 \mu \mathrm{m}$, respectively (Hogentogler, Columbia, MD), to isolate the eriophyid mites. The 500 mesh was rinsed into a counting 
36 square Petri plate, where a total of five squares were counted for a plate average. The plate average mite count was then divided by 10 , the number of grams of rose tissue that were used in the sample, to find the number of mites per gram of rose tissue.

\section{Statistical Analysis}

A mixed model analysis of variance was performed using the MIXED procedure of SAS (Littell et al. 2006) to determine whether the fixed effects of RRV infection status, hour, cut type, or rose species were associated with the number of mites per gram of tissue. In addition, the random effects of the individual plants and the combined effect of the individual plant and the hour it was processed were included in the model. Orthogonal polynomial contrasts were performed to determine if there were curvilinear relationships between hourly measurements and mites per gram. Least square means were reported, and significant effects were determined using a level of significance of $\alpha=0.05$.

\section{Cut Type and Species Effect on Mites Counts}

The goal of this experiment was to determine the effects of floral cut treatments on the retention of eriophyid mites on rose cuttings. There was no statistical difference observed in mites per gram between cut types (floral cut or dry cut) $(P=0.87)$ or between rose species $(P=0.76)$. Dry cuts had an average of $4.8 \mathrm{mites} / \mathrm{g}$, whereas samples from floral cuts had an average of $4.6 \mathrm{mites} / \mathrm{g}$.

\section{Hours Postharvest Mite Counts}

The hour, or the amount of time postharvest, affected mites per gram $(P=0.046)$, and orthogonal polynomial contrasts indicated a cubic relationship between hour and the number of mites per gram $(P=0.011)$. Mites per gram decreased steadily from 0.5 to $48 \mathrm{~h}$. At $72 \mathrm{~h}$ there was an increase in mites per gram and a subsequent numerical decrease in mites per gram at $96 \mathrm{~h}$ (Fig. 1).

\section{RRV Infection Effect on Mite Counts}

The number of mites per gram was significantly associated with whether the plant was infected with RRV or not $(P=0.0002)$. On average, there were greater numbers of mites per gram in RRVinfected plants compared with plants without RRV. Plants infected with RRV had $9.21 \pm 1.7$ mites $/ g$, whereas RRV-free plants had $0.20 \pm 1.7 \mathrm{mites} / \mathrm{g}$ of rose tissue (nonspecific rose species).

\section{TaqMan RT-qPCR}

Composite samples for TaqMan RT-qPCR analysis were collected the following spring from each plot for confirmation of RRV presence or absence. A critical threshold $(\mathrm{Ct})$ value indicates amplification of RRV RNA, and therefore the sample is positive for $\mathrm{RRV}$. Samples in which a $\mathrm{Ct}$ value is undetermined indicate that RRV RNA is not present, and therefore the sample is negative for RRV. The symptomatic Knock Out and multiflora plots tested positive for RRV with Ct values of 24.013 and 28.776, respectively. The asymptomatic Knock Out and multiflora roses were negative for RRV (Table 1).

\section{Conclusions and Implications for Future Techniques}

This study evaluated the necessity of using a floral cut treatment on the retention of mites on a rose cutting. These results will impact

\begin{tabular}{|c|c|c|}
\hline \multicolumn{3}{|c|}{ 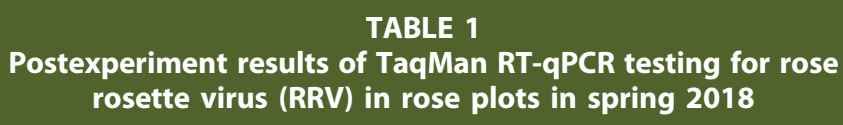 } \\
\hline Plot type & Ct value ${ }^{\mathrm{a}}$ & RRV \\
\hline Asymptomatic Knock Out roses & Undetermined & Negative \\
\hline Symptomatic Knock Out roses & 24.013 & Positive \\
\hline Asymptomatic multiflora roses & Undetermined & Negative \\
\hline Symptomatic multiflora roses & 28.773 & Positive \\
\hline Negative control (RNAase-free water) & Undetermined & Negative \\
\hline Negative control (asymptomatic rose) & Undetermined & Negative \\
\hline Positive control (fresh sample) & 30.972 & Positive \\
\hline Positive control (frozen sample) & 28.755 & Positive \\
\hline
\end{tabular}

${ }^{\mathrm{a}} \mathrm{Ct}=$ critical threshold, and undetermined $=$ no amplification, negative.

\section{Mite counts at time intervals postharvest}

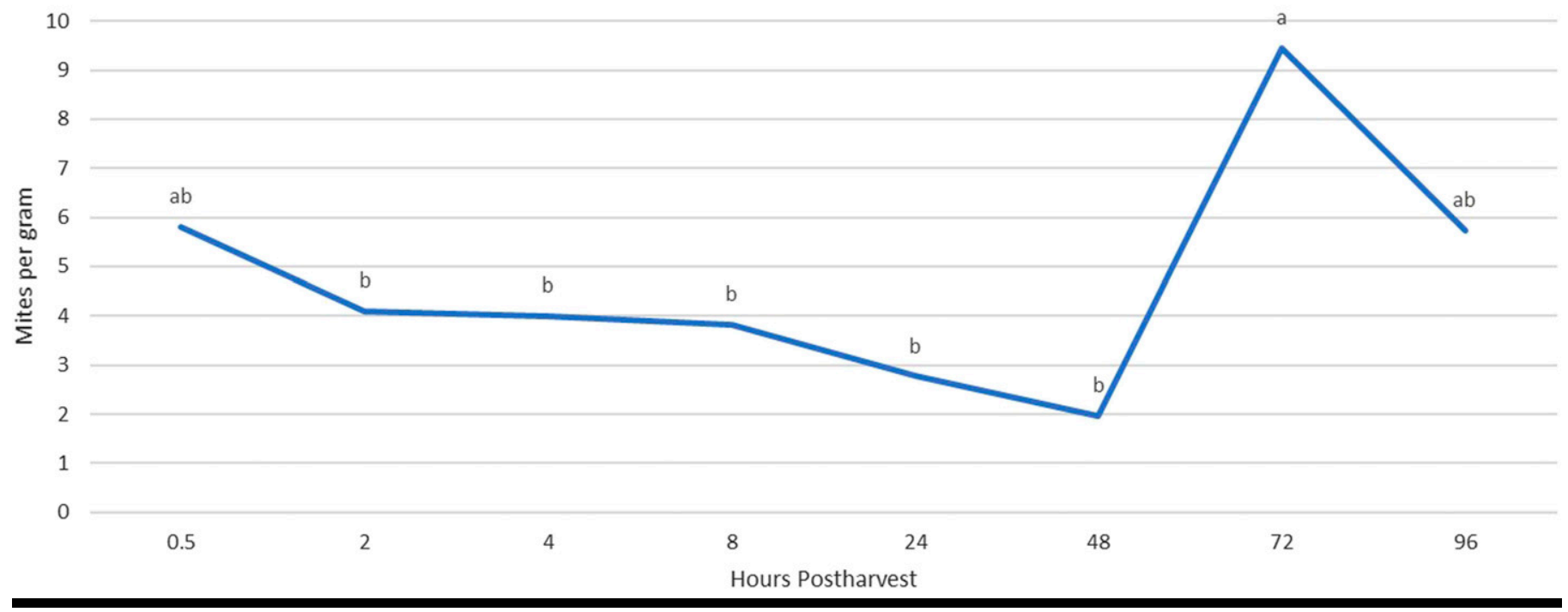

FIGURE 1

Number of eriophyid mites per gram of rose tissue at time intervals postharvest. Knock Out and multiflora roses were evaluated in October 2017 for eriophyid mites. Data are reported in mean squares with two replications, including 350 degrees of freedom and $P=0.05$. 
the collection techniques currently used in the study of eriophyid mite populations.

Floral cuts were previously used to reduce the change in xylem hydraulic conductance that may trigger eriophyids to abandon their rose host. This study did not detect significant differences between the numbers of mites per gram in samples from floral or dry cuts, disproving the first hypothesis. This suggests that floral cuts may not be necessary to preserve mite populations on rose cuttings. If floral cuts are no longer needed, collecting rose samples in the field may be conducted faster. Additionally, the cuttings would undergo less handling that could also dislodge mites from the sample. This will not only affect day-to-day sampling and monitoring for eriophyid mites but will also streamline large-scale RRV inoculations by vectors in research plots. These data suggest that the mites are more tolerant to changing microenvironments on the host than previously thought. Future studies should consider the role of temperature, humidity, and water stress to see whether these factors affect eriophyid mite retention in rose tissue.

This experiment was designed to test mite population retention on rose cuttings but also to incorporate the possibility that cultivated roses such as Knock Out roses, which are widely planted in commercial locations, and naturalized species such as $R$. multiflora may retain mites differently. The statistical analysis indicated that no preference was shown in mite retention in either Knock Out or multiflora roses. The number of mites per gram of rose tissue was similar between Knock Out roses and multiflora species. This supports the hypothesis that there is no difference in the number of mites found in either Knock Out or multiflora roses.

There have been numerous accounts comparing the number of mites found on RRD symptomatic roses versus asymptomatic roses (Amrine 1996; Epstein and Hill 1999; Jesse et al. 2006), but all previous data were found in $R$. multiflora. Because $\mathrm{RRV}$ is as much of a threat to cultivated species of roses as it is to naturalized species, new data looking at cultivated roses are needed to determine whether similar vector interactions are observed. As hypothesized, data in this study support previous findings with a multifold increase of eriophyid mites found on RRD-infected $R$. multiflora cuttings versus RRD-free tissue (Amrine 1996; Epstein and Hill 1999; Jesse et al. 2006). Similar data were collected with the cultivated Knock Out shrub rose with a 46-fold increase of mites per gram of tissue between RRVinfected tissue (9.21 mites/g) and RRV-free tissue ( $0.20 \mathrm{mites} / \mathrm{g})$. This will be an important factor in future studies measuring eriophyid mite populations on roses with and without RRV infections.

This study showed there was a numerical decline in mites per gram over the first $48 \mathrm{~h}$, but the means were not significantly different. Often it is not practical to process all samples within a short window, such as $0.5 \mathrm{~h}$, owing to location of sample plots and labs. In future research, these data will give confidence that sample collection and mite isolation processing that occurs within $48 \mathrm{~h}$ of harvesting will yield consistent results. The significant increase of mites at the 72-h interval could be attributed to eggs hatching on the plant tissue, which takes an average of 4.3 days from the time the eggs are laid to hatch (Kassar and Amrine 1990). Another possible scenario is that mites hidden in deep microenvironments could be relocating to new feeding locations and more vulnerable to isolation processing.

Overall, this study answered an important question about the resiliency of refuge-seeking eriophyid mites on rose cuttings. Laboratory techniques that require rose cuttings for mite extraction can now be conducted much more efficiently, requiring less time and less handling of the samples.

\section{Literature Cited}

Allington, W. B., Staples, R., and Viehmeyer, G. 1968. Transmission of rose rosette virus by the eriophyid mite Phyllocoptes fructiphilus. J. Econ. Entomol. 61:1137-1140.

Amrine, J. W. 1996. Phyllocoptes fructiphilus and biological control of multiflora rose. Pages 741-749 in: Eriophyoid Mites-Their Biology, Natural Enemies and Control. E. E. Lindquist, M. W. Sabelis, and J. Bruin, eds. Vol. 6. Elsevier Science Publishing, Amsterdam, Netherlands.

Amrine, J. W., Jr., Hindal, D. F., Stasny, T. A., Williams, R. L., and Coffman, C. C. 1988. Transmission of the rose rosette disease agent to Rosa multiflora by Phyllocoptes fructiphilus (Acari: Eriophyidae). Entomol. News 99: 239-252.

Babu, B., Washburn, B. K., Ertek, T. S., Miller, S. H., Riddle, C. B., Knox, G. W., Ochoa-Corona, F. M., Olson, J., Katırcıoğlu, Y. Z., and Paret, M. L. 2017. A field based detection method for rose rosette virus using isothermal probe-based reverse transcription-recombinase polymerase amplification assay. J. Virol. Methods 247:81-90.

Bergh, J. C., and Weiss, C. R. 1993. Pear rust mite, Epitrimerus pyri (Acari: Eriophyidae) oviposition and nymphal development on Pyrus and non-Pyrus hosts. Exp. Appl. Acarol. 17:215-224.

Davis, R. 1964. Autecological studies of Rhynacus breitlowi Davis (Acarina: Eriophyidae). Fla. Entomol. 47:113-121.

Dobhal, S., Olson, J. D., Arif, M., Garcia Suarez, J. A., and Ochoa-Corona, F. M. 2016. A simplified strategy for sensitive detection of rose rosette virus compatible with three RT-PCR chemistries. J. Virol. Methods 232: 47-56.

Epstein, A. H., and Hill, J. H. 1999. Status of rose rosette disease as a biological control for multiflora rose. Plant Dis. 83:92-101.

Evans, R. Y., Zheng, J. M., and Reid, M. S. 1996. Structural and environmental factors affecting the postharvest life of cut roses. Acta Hortic. 424: 169-174.

Faraji, F., Bruin, J., and Bakker, F. 2004. A new method for mite extraction from leaf samples. Exp. Appl. Acarol. 32:31-39.

Gabi, G., and Mészáros, Z. 2001. New data to the knowledge of Calepitrimerus vitis Nalepa in the vine-growing region of Szekszárd, Hungary (Acari: Eriophyidae). Acta Phytopathol. Entomol. Hung. 36:193-200.

Gergerich, R., and Kim, K. 1983. A description of the causal agent of rose rosette disease. Arkansas Farm Res. 32(3):7.

Jesse, L. C., Moloney, K., and Obrycki, J. 2006. Abundance of arthropods on the branch tips of the invasive plant, Rosa multiflora (Rosaceae). Weed Biol. Manage. 6:204-211.

Kassar, A., and Amrine, J. W., Jr. 1990. Rearing and development of Phyllocoptes fructiphilus (Acari: Eriophyidae). Entomol. News 101:276-282.

Keifer, H. H. 1940. Eriophyid Studies VIII. Bull. Cali. Dept. Agric. 29: 21-46.

Krantz, G. 1973. Observations on the morphology and behavior of the filbert rust mite, Aculus comatus (Prostigmata: Eriophyoidea) in Oregon. Ann. Entomol. Soc. Am. 66:709-717.

Laney, A. G., Keller, K. E., Martin, R. R., and Tzanetakis, I. E. 2011. A discovery 70 years in the making: Characterization of the rose rosette virus. J. Gen. Virol. 92:1727-1732.

Littell, R. C., Milliken, G. A., Stroup, W. W., Wolfinger, R. D., and Schabenberger, O. 2006. SAS for Mixed Models, 2nd Ed. SAS Institute, Cary, NC.

Michalska, K., Skoracka, A., Navia, D., and Amrine, J. 2010. Behavioural studies on eriophyoid mites: An overview. Exp. Appl. Acarol. 51: 31-59.

Monfreda, R., Nuzzaci, G., and De Lillo, E. 2007. Detection, extraction, and collection of eriophyoid mites. Zootaxa 1662:35-43.

Nault, L. R., and Styer, W. E. 1969. The dispersal of Aceria tulipae and three other grass-infesting eriophyid mites in Ohio. Ann. Entomol. Soc. Am. 62: 1446-1455.

Pérez-Moreno, I., and Moraza-Zorilla, M. L. 1998. Population dynamics and hiberation shelters of Calepitrimerus vitis in the vineyards of Rioja, Spain, with a description of a new eriophyid extraction technique (Acari, Eriophyidae). Exp. Appl. Acarol. 22:215-226.

Sabelis, M. W., and Bruin, J. 1996. Evolutionary ecology: Life history patterns, food plant choice and dispersal. Pages 329-366 in: World Crop Pests-Their Biology, Natural Enemies, and Control, vol. 6. Elsevier Science Publishing, Amsterdam, Netherlands.

Shevchenko, V. 1970. Origin and morpho-functional analysis of tetrapod mites. Pages 153-183 in: Studies on Evolutionary Morphology of Invertebrates. 
L. A. Evdonin, ed. Leningrad University Press, Leningrad, USSR. (In Russian.)

Shvanderov, F. A. 1975. Role of phoresy in the migration of eriophyoid mites (Eriophyoidea). Zool. Zh. 54:458-461.

Siriwardena, P., Fernando, L., and Peiris, T. 2005. A new method to estimate the population size of coconut mite, Aceria guerreronis, on a coconut. Exp. Appl. Acarol. 37:123-129.

Smith, B. D. 1959. The behaviour of the black currant gall mite (Phytoptus ribis Nal.) during the free living phase of its life cycle. Pages 130-136 in: Annual Report, Long Ashton Agricultural and Horticultural Research Station, Bristol.
Westphal, E., Dreger, F., and Bronner, R. 1990. The gall mite Aceria cladophthirus life-cycle, survival outside the gall, and symptoms' expression on susceptible or resistant Solanum dulcamara plants. Exp. Appl. Acarol. 9:183-200.

Westphal, E., and Manson, D. C. M. 1996. Feeding effects on host plants: Gall formation and other distortions. Pages 231-242 in: Eriophyoid Mites-Their Biology, Natural Enemies and Control. E. Lindquist, M. Sabelis, and J. Bruin, eds. Vol. 6. Elsevier Science Publishing, Amsterdam, Netherlands.

Zacharda, M., Pultar, O., and Muška, J. 1988. Washing technique for monitoring mites in apple orchards. Exp. Appl. Acarol. 5:181-183. 